\title{
Astronomiczne zagadki w Historii naturalnej Pliniusza Starszego
}

\section{Astronomical Riddles in the Natural History by Pliny the Elder}

Gajusz Pliniusz Sekundus, Historia naturalna. T. I: Kosmologia i geografia, księgi II-VI, tekst, wstęp, tłum. i komentarz I. Mikołajczyk, N. Rataj, E. Twarowska-Antczak, K. Antczak, red. I. Mikołajczyk, Wydawnictwo Naukowe UMK, Toruń 2017, ss. 759.

Gajusz Pliniusz Sekundus, Historia naturalna. T. II: Antropologia i zoologia, księgi VII-XI, tekst, wstęp, tłum. i komentarz I. Mikołajczyk, Wydawnictwo Naukowe UMK, Toruń 2019, ss. 674.

The article presents selected problems related to the Latin-Polish critical edition of the first two volumes of the Natural History by Pliny the Elder. With regard to several passages from this ancient encyclopedia, which are important for the history of astronomy, the text pinpoints the insufficiency and some inaccuracies in the scientific commentary to the second book on cosmology, both in terms of content and sources. On the selected examples from the second volume, pertaining to anthropology and zoology, the article criticizes - in comparison to previous Polish translations - the text of the new one, which is sometimes significantly inconsistent with the Latin original.

Keywords: Pliny the Elder, Natural History, ancient astronomy, translation criticism

Słowa kluczowe: Pliniusz Starszy, Historia naturalna, astronomia starożytna, krytyka przekładu

W jaki sposób opracować naukowe wydanie monumentalnej encyklopedii z czasów Cesarstwa Rzymskiego, zestawiającej dwadzieścia tysięcy faktów na podstawie dwóch tysięcy tomów stu wybranych autorów? Informacje z kompilowanych przez Pliniusza prac, obecnie w dużej mierze zaginionych, niełatwo jest weryfikować, mając do dyspozycji często tylko późniejsze i pośrednie przekazy. Klasyfikacjami i rejestrami obejmuje encyklopedysta całość znanego świata fizycznego, jego podziały geograficzne, człowieka z podporządkowaną mu hierarchią natury ożywionej i nieożywionej, gromadząc w swoim katalogu wiedzę ze specjalistycznych dziedzin, od kosmologii i geografii, przez antropologię, zoo- 
logię, botanikę i medycynę po mineralogię. Tak zróżnicowane kompendium zawiera liczne terminy fachowe, które nabrały obecnie niekiedy odmiennego znaczenia. Dane czy twierdzenia przedstawiane przez Pliniusza, czasem dodatkowo zniekształcone w procesie rękopiśmiennej transmisji tekstu, domagają się skonfrontowania ze współczesnym stanem wiedzy oraz żmudnych i drobiazgowych dociekań nad historią szczegółowych zagadnień z zakresu rozmaitych dyscyplin naukowych. O ile oczywiście ustalono wcześniej poprawnie sens, jaki swej często niejednoznacznej wypowiedzi chciał nadać piszący enigmatycznie i eliptycznie autor. Omówię tutaj kilka wybranych problemów, z jakimi musiał zmierzyć się zespół toruńskich historyków i filologów, opracowując pierwsze dwa tomy Historii naturalnej (księgi 2-11) ${ }^{41}$, a przyjęte przez nich rozwiązania poddam próbie oceny. Analiza merytoryczna obejmie głównie kosmologiczną księgę drugą, krytyka przekładu zaś przeprowadzona będzie szczególnie w odniesieniu do tomu drugiego, antropologiczno-zoologicznego.

Komentarz do kosmologii (przypisy do księgi 2), w którym zestawiono podstawowe wiadomości historyczne, geograficzne i biograficzne, wydaje się wyjęty z szerszego kontekstu literatury starożytnej. Często, co prawda, źródła Pliniusza znane są tylko z zamieszczonych w encyklopedii ekscerptów i streszczeń, nie oznacza to jednak, że nie należy podejmować trudu identyfikowania, zwłaszcza tych dobrze zachowanych. I tak, ku zdziwieniu czytelnika, w edycji księgi drugiej tylko sporadycznie pojawiają się odniesienia do traktatów Arystotelesa (3), pism Cycerona (4), O zjawiskach natury Seneki Młodszego (5), Warrona (1), Witruwiusza (1) czy poematu Maniliusza (2), podczas gdy cytatów, nawiązań, parafraz i similiów kryje się w Historii naturalnej znacznie więcej, niż zaznaczono. Nie opatrzono przypisem chociażby wypowiedzi: „Arystoteles twierdzi, że kiedyś widziano tęczę w nocy", 2, 60,150, s. 135, choć można przecież ustalić, że Pliniusz cytuje tu Meteorologika, 3, 2, 372a. Pisząc w 2, 83, 196, s. 163, o poprzedzającym trzęsienie ziemi znaku w postaci cienkiej i długiej linii chmur, przekłada encyklopedysta niemal dosłownie Meteorologika, 2, 8, 367b; podobnie w passusie o niezmierzonej głębokości Morza Czarnego z 2, 105, 224, s. 181 - Meteorologika, 1, 13, 351a. Wyciągiem $z$ tego samego traktatu, 1, 10-12, jest także rozdział o gradzie, rosie i szronie w 2, 61, 152 , s. 135. Krytyka antropomorfizujących opowieści o bogach w 2, 5, 17-19, s. 61, wykazuje podobieństwa z rozważaniami Cycerona w $O$ naturze bogów, 1, 30, 83; 1, 16, 42 oraz 2, 24, 62. Z traktatu $O$ wróżbiarstwie mógł Pliniusz korzystać, przytaczając w 2, 55, 142, s. 129 wiadomość o tym, że Etruskowie podzielili niebo na szesnaście części (u Cycerona 2, 18, 42), a w 2, 81, 191, s. 159 - historię o boskiej zdolności przewidzenia trzęsienia ziemi przez Ferekydesa po upadku do studni (u Cycerona 2, 13, 31). W kwestii liczby wiatrów w 2, 46, 119, s. 115-117, nie wspomniano w komentarzu o klasyfikacji Warrona u Seneki, O zjawiskach natury, 5, 16, 3, oraz o podziałach u Witruwiusza według $O$ architekturze, 1, 6, 4. Zaczerpnięta z traktatu $O$ zjawiskach natury, 3, 25, 8, może być opowieść o lesie na jeziorze Wadymońskim w pobliżu źródeł kutilskich w 2, 96, 209, s. 173. Podobnie w wywodzie o oczyszczaniu mórz w czasie pełni w 2, 101, 220, s. 179, parafrazuje Pliniusz pismo Seneki, 3, 26, 7. W O zjawiskach natury, 3, 25, 4, znajduje się

41 Gajusz Pliniusz Sekundus, Historia naturalna. T. II: Kosmologia i geografia, księgi II-VI, tekst, wstęp, tłum. i komentarz I. Mikołajczyk, N. Rataj, E. Twarowska-Antczak, K. Antczak, red. I. Mikołajczyk, T. II: Antropologia i zoologia, księgi VII-XI, tekst, wstęp, tłum. i komentarz I. Mikołajczyk, Toruń 2017-2019. 
także podobna wzmianka o rzekach, których wody farbują owcom wełnę na różne kolory (jak u Pliniusza w 2, 106, 230, s. 185), etymologię zaś rzeki Skamander, nadającej owcom żółtą barwę, przekazuje Arystoteles w Zoologii, 3, 12, 519a. Do Epistolicarum quaestionum Warrona, których fragment zachował się u Festusa w De verborum significatu, mógł odnosić się Pliniusz, pisząc w 2, 55, 142, s. 129, o tym, że pioruny z lewej strony uchodzą za znaki pomyślne. Również fragment Rerum humanarum Warrona, 13, 3, przekazany przez Aulusa Gelliusza w Nocach attyckich, 3, 2, 4-7, wydaje się źródłem relacji Pliniusza o sposobach pomiaru czasu przez Babilończyków, Ateńczyków, Umbrów i Rzymian w 2, 79, 188, s. 157. Odnośnie do długości cienia dla Rzymu według 2, 74, 182, s. 155 można porównać dane Pliniusza (cień o 1/9 krótszy od gnomonu) z tekstem $O$ architekturze Witruwiusza, 9, 7, 1 (cień równy 8/9 długości wskazówki). Z kolei w Astronomica, 1, 216, również Maniliusz wspomina o niewidoczności gwiazdy Kanopus w Italii (u Pliniusza w 2, 71,178 , s. 151). Podsumowując powyższą, opartą na wcześniejszych wydaniach krytycznych i zaledwie przeglądową analizę źródłową księgi drugiej, należy stwierdzić brak w komentarzu wielu istotnych dla Pliniuszowej kosmologii odniesień, którymi tłumacze nie chcieli zapewne nadmiernie obciążać tekstu. Pominięcie jednak przynajmniej niektórych z nich wydaje się istotnym defektem nowego opracowania.

W notach do księgi drugiej bardzo pobieżnie przedstawiono zagadnienia dotyczące historii astronomii oraz wpływy nauki greckiej obecne w często niejasnych twierdzeniach $\mathrm{Hi}$ storii naturalnej. Być może dzieje się tak dlatego, że ze sprawozdania Pliniusza z trudem tylko można poznawać astronomię hellenistyczną okresu między Hipparchem a jego czasami, encyklopedysta nie dysponował bowiem ani dostatecznym zrozumieniem popularyzowanej przez siebie nauki, ani odpowiednią łacińską terminologią techniczną. Zaczynając od nieanalizowanych w komentarzu dokładniej stoickich motywów w kosmologii Pliniusza, można z łatwością ustalić, że kilkakrotnie powtarzany pogląd o tym, jakoby gwiazdy żywiły się wilgocią ziemską, Księżyc wodami słodkimi, Słońce morskimi (2, 6, 46, s. 71; 104, 223, s. 181), pochodzi od Zenona i Chryzypa, najprawdopodobniej za pośrednictwem Posejdoniosa, o czym wiadomo choćby z przekazów Cycerona $O$ naturze bogów, 2, 46, 118, oraz Diogenesa Laertiosa Żywotów i poglądów słynnych filozofów, 7, 1, 144. Z kolei nieprawidłowo odniesiona w edycji wydaje się pierwotnie pitagorejska, a rozpropagowana przez Posejdoniosa i stoików koncepcja wielkiego roku (ratio magni anni) z 2, 6, 40, s. 69. Na podstawie tego passusu Olaf Pedersen stwierdza, że Pliniusz był jej świadom, lecz nie powrócił w księdze pierwszej do tego pojęcia ${ }^{42}$. Natomiast z not w toruńskim komentarzu, gdzie przypis 55 odsyła do paragrafu 56 tej samej księgi, wynikałoby, że wielki rok, czyli „czas życia wszechświata od zagłady do zagłady, wyznaczony przez koniunkcje wszystkich planet", można objaśnić przez porównanie z babilońskim sarosem, ponadosiemnastoletnim „okresem, w którym Ziemia, Słońce i Księżyc wracają do prawie takiego samego położenia względem siebie", czyli powtarzalnym cyklem zaćmień ${ }^{3}$. Taka asocjacja wydaje się niedorzeczna ${ }^{44}$.

42 O. Pedersen, Some Astronomical Topics in Pliny, [w:] Science in the Early Roman Empire: Pliny the Elder, His Sources and Influence, red. R. French, F. Greenaway, London - Sydney 1986, s. 176.

43 Więcej na jego temat w: J. Włodarczyk, Księżyc w nauce i kulturze Zachodu, Poznań 2012, s. 96, z odniesieniem do: E. Halley, Emendationes et notae in tria loca vitiose edita in textu vulgato Naturalis Historiae C. Plinii, „Philosophical Transactions" t. 16, 1686-1692, s. 535-540.

44 Inne użycie tego terminu w: t. 2, 10, 2, 5, s. 339, gdzie wielki rok przypada na 540-letni okres życia feniksa; w przypisie 16, s. 623, objaśnienie za Cyceronem, O naturze bogów, 2, 51. Według przekazu Aecjusza niektórzy 
Komentarza bardziej objaśniającego (niż tylko krótki biogram) wymagałby passus w 2 , 9, 53, s. 75, w którym Pliniusz stwierdza, że Hipparch „przewidział bieg obu ciał niebieskich [Słońca i Księżyca] na 600 lat" (utriusque sideris cursum in sexcentos annos praececinit). Można było odwołać się tu do monografii na gruncie polskim ${ }^{45}$ lub rekonstruować sens tego stwierdzenia na podstawie toczących się wciąż dyskusji. Zgodnie z niektórymi rękopisami proponowano usunąć z frazy cursum, a zamiast niego rozumieć defectus (Jean Beaujeu, Wilhelm Kroll), co również nie poprawiało radykalnie sensu zdania. Tak odczytując tekst, entuzjastycznemu zwolennikowi Hipparcha zarzucono, że zupełnie nie pojmował matematycznego ogromu dokonań przypisywanych astronomowi (przewidzenie zaćmień Słońca i Księżyca na okres kolejnych 600 lat). Zdaniem Ottona Neugebauera bardziej prawdopodobne jest, że praca Hipparcha polegała raczej na zebraniu i opracowaniu zgromadzonych przez astronomów babilońskich danych dotyczących wcześniejszych zaćmień (z okresu ok. 721-127 p.n.e.) ${ }^{46}$. Na tej podstawie Pedersen zaproponował nawet emendację tekstu recicinit, czyli „powtórzył” ${ }^{47}$. Inne rozwiązanie przedstawili Bernard R. Goldstein i Alan C. Bowen ${ }^{48}$, według których cursus oznaczałby tu ruch dzienny Księżyca i Słońca, a sześćsetlecie wygodny, przybliżony cykl obliczeniowy przy rozpoczęciu od określonej daty. Pliniusz mógłby zatem przypisywać Hipparchowi boską zdolność przewidzenia zaćmień na podstawie teorii arytmetycznej. Wiązałoby się to oczywiście z wieloma obliczeniami, jak przyznaje Bowen, lecz należy wziąć pod uwagę późniejsze świadectwo bizantyńskiego historyka Jana Lydosa z De ostentis, zgodnie z którym Hipparch ustalił zaćmienie Słońca na sześćset lat do przodu ${ }^{49}$.

W dużym uproszczeniu skomentowano również enigmatyczną wypowiedź Pliniusza, dotyczącą odkrycia nowej gwiazdy (novam stellam et aliam), która miała zainspirować Hipparcha do ułożenia katalogu gwiazd (2, 24, 95, s. 99, przypisy 151-152). Przedstawiona w przypisie interpretacja jest najczęściej przyjmowaną, choć nie jedyną ${ }^{50}$. Z kontekstu mogłoby wynikać, że mowa raczej o gwieździe w ruchu, czyli o komecie lub meteorze, wspomniana wypowiedź usytuowana jest bowiem między opisem jednych i drugich. Tak też interpretował to zjawisko John Knight Fotheringham, który identyfikował je z kometą 134 r. p.n.e., opisywaną w źródłach chińskich ${ }^{51}$. Z kolei jakby przeciwko możliwości takiego rozumienia tekstu w niektórych przekazach rękopiśmiennych dodawano et aliam, chcąc podkreślić, że nowa gwiazda różniła się jednak od komet. Wyrażano także opinię, że passus mógł zostać w obrębie tekstu przestawiony. Jako jeszcze inną możliwość pro-

utożsamiali wtórnie koncepcję wielkiego roku z oktaeterydą lub dziewiętnastoletnim cyklem Metona, co nie miało jednak wiele wspólnego z pierwotną wizją zgłady świata, por. R. van der Broek, The Myth of the Phoenix according to Classical and Early Christian Traditions, Leiden 1972, s. 75-76. Notabene w przypisach nie wyjaśniono także pojęcia oktaeterydy, por. 2, 99, 215, s. 175.

45 Por. J. Włodarczyk, Księżyc w nauce $i$ kulturze Zachodu, s. 119.

46 O. Neugebauer, A History of Ancient Mathematical Astronomy, Berlin - Heidelberg - New York 1975, t. 1, s. 319-321.

47 O. Pedersen, Some Astronomical Topics in Pliny, s. 192-194.

48 B.R. Goldstein, A.C. Bowen, Pliny and Hipparchus's 600-Year Cycle, "Journal for the History of Astronomy” t. 26,1995 , s. $156-157$.

49 A.C. Bowen, The Art of the Commander and the Roman Emergence of Predictive Astronomy, [w:] Science and Mathematics in Ancient Greek Culture, red. C.J. Tuplin, T E. Rhill, New York 2002, s. 106-107.

50 Por. D.H. Clark, R.F. Stephenson, The Historical Supernovae, Oxford - New York - Toronto - Sydney - Paris Frankfurt 1977, s. 14; G.E.R. Lloyd, Nauka grecka po Arystotelesie, tłum. J. Lesiński, Warszawa 1998, s. 74 i n.

51 J.K. Fotheringham, The New Star of Hipparchus, and the Dates of the Birth and Accession of Mithridates, „Monthly Notices of the Royal Astronomical Society" t. 79, 1919, s. 167. 
ponowano przyjąć jakościowe znaczenie ruchu, zgodnie z którym wątpliwości Hipparcha dotyczyłyby raczej zmian jasności gwiazd - przy takiej interpretacji nie musiałby on odkryć gwiazdy nowej52. Co do samego katalogu Hipparcha świadectwo Pliniusza wydaje się mało precyzyjne i niezbyt wiarygodne, nie znajduje bowiem bezpośredniego potwierdzenia w przekazie Ptolemeusza, który nie cytuje takiego katalogu ${ }^{53}$, choć jednocześnie wiadomo, że korzystał z danych zgromadzonych przez poprzednika i utrwalił je przynajmniej częściowo w swojej pracy ${ }^{54}$. Być może więc w taki sposób Pliniusz wspomina tu komentarz Hipparcha do Fenomenów Aratosa i Eudoksosa.

Podobnie niemałych trudności dostarcza historykom nauki inna ogólnikowa wypowiedź encyklopedysty w 2, 41, 110, s. 111 - w polskim wydaniu nieopatrzona żadnym przypisem - według której uczeni (periti) dokonali podziału nieba na 72 znaki, „to znaczy obrazy rzeczy lub zwierząt" i doszukali się 1600 gwiazd. Trudno jest badać początki greckich katalogów gwiazd, czego wzmianka Pliniusza tym bardziej nie ułatwia. Według Aratosa z Soloj byłoby to 51 asteryzmów (46 pochodzących ze wcześniejszej tradycji oraz 5 szczególnych, które z czasem utraciły swój status), z kolei według Hipparcha - 46 konstelacji z liczbą 653 gwiazd, według Ptolemeusza - 48 konstelacji z 1022 gwiazdami oraz 22 grupy niezrzeszonych ${ }^{55}$. Jak zatem rozumieć zawyżone wartości podane przez Pliniusza? We wcześniejszym wywodzie w 2, 3, 7, s. 57, wspominał on mgliście niezliczone wizerunki zwierząt oraz przedmiotów (innumeras effigies animalium rerumque cunctarum) odbite na sklepieniu wszechświata, co nie wyjaśnia precyzyjniejszego podziału. Przypuszczano dawniej, że Pliniusz uznawał być może części gwiazdozbiorów za całe gwiazdozbiory. Powtarzano również opinię Josepha Justusa Scaligera z komentarza do Astronomica Maniliusza, że podana przez Pliniusza wartość uległa zepsuciu w procesie transmisji tekstu i dlatego należy odczytywać ją nie jako duo atque septuaginta, lecz duodequinquaginta (a zatem Ptolemeuszowe $48)^{56}$. Wyjaśniano też, że liczbę tę mógł uzyskać Pliniusz, dodając do znanych 48 konstelacji dwie pomijane (przez Ptolemeusza) Warkocz i Antinous, a ponadto 22 grupy niezrzeszonych ${ }^{57}$ - taka interpretacja wydaje się jednak za bardzo oparta na późniejszych danych z Almagestu. Według obecnie przyjmowanego przez historyków nauki wyjaśnienia (od czasów Franza Bolla) Pliniusz myli tu najprawdopodobniej 12 konstelacji zodiaku z 36 dekanami egipskimi i dodaje do tego 36 gwiazdozbiorów pozazodiakalnych ${ }^{58}$.

Z wymienianych przez Pliniusza konstelacji nader zwięźle opisano w przypisie 299 do 2, 71, 178, s. 151, zagadkowy gwiazdozbiór Tron Cezara (Caesaris thronos) (tj. Oktawiana

O. Pedersen, Some Astronomical Topics in Pliny, s. 192.

53 Idem, A Survey of the Almagest with Annotation and New Commentary by Alexander Jones, New York - Dordrecht - Heidelberg - London 2011, s. 258.

54 Idem, Early Physics and Astronomy: A Historical Introduction, Cambridge 1993, s. 49.

55 J. Włodarczyk, Early Star Catalogues or What Do We Really Know About Ancient Observational Procedures of Positional Measurements, [w:] Science in Contact at the Beginning of Scientific Revolution, red. J. Zamrzlová, Prague 2004 (Acta historiae rerum naturalium necnon technicarum, New Series, t. 9), s. 84, 87; J. Dobrzycki, Historia naturalna gwiazdozbiorów I: wstęp do studiów nad ikonografią nieba gwiaździstego, „Kwartalnik Historii Nauki i Techniki" t. 34, 1989, nr 4, s. 898-899.

56 R.H. Allen, Star-Names and Their Meanings, New York 1936, s. 11.

57 J.L.E. Dreyer, On the Origin of Ptolemy's Catalogue of Stars, „Monthly Notices of the Royal Astronomical Society" t. 77, 1917, s. 529.

58 O. Neugebauer, A History of Ancient Mathematical Astronomy, t. 1, s. 284-286; O. Pedersen, Some Astronomical Topics in Pliny, s. 174; Pline I'Ancien, Histoire naturelle. Livre II, tekst, tłum. i komentarz J. Beaujeu, Paris 1950, s. 190-191. 
Augusta): „Nie wiadomo, o jakiej dokładnie konstelacji mówi Pliniusz”, choć można zebrać niemało odnośnych informacji. Poza encyklopedystą nie wspomina o niej żaden inny autor starożytny. Od dawna panowała jednak opinia, że Pliniusz mógł pod tą nazwą odnosić się do Krzyża (Crux), widocznego z Aleksandrii i określonego tym mianem prawdopodobnie przez któregoś z astronomów nadwornych ${ }^{59}$. Sam jednak pomysł wyodrębnienia nowej konstelacji z gwiazd Krzyża, należących w kanonie hellenistycznym do Centaura, okazał się chybiony i przetrwał jedynie w krótkiej wzmiance Pliniusza ${ }^{60}$. Ponadto pojawiła się kontrowersyjna hipoteza Bolla, że prostokątny obiekt w kształcie kraty na Globusie Farnezyjskim, przypominający krzesło z wysokim oparciem, może być przedstawieniem właśnie Tronu Cezara. Konstelację próbowano także łączyć z gwiazdą czy kometą, która ukazała się w północnej części nieba jako dowód apoteozy Cezara w trakcie igrzysk pośmiertnych, urządzonych przez Oktawiana Augusta $\left(2,23,94\right.$, s. 99) w 44 r. p.n.e. ${ }^{61}$ W podanej przez Pliniusza nazwie gwiazdozbioru dopatrywano się nawet świadectwa katasteryzmu Cezara, choć może się to wydawać dziełem fantazji encyklopedysty ${ }^{62}$. Interpretacje te jednak są obecnie poddawane krytyce ${ }^{63}$, głównie ze względu na różne pomyłki czy zepsucia wspomnianego miejsca Historii naturalnej, choćby to, że wbrew opinii Pliniusza Warkocz Bereniki jest dostępny obserwacjom w Italii ${ }^{64}$. Wykluczono również ikonograficznie możliwość przedstawienia tronu na Globusie Farnezyjskim ${ }^{65}$.

Przytaczane przez Pliniusza dane i fakty dotyczące historii astronomii są często niespójne, nieadekwatne lub archaiczne w stosunku do ówczesnego stanu wiedzy i mogą być efektem niezrozumienia referowanej teorii, a wypowiedzi encyklopedysty zaprzeczają przekazom z innych źródeł. Tego typu trudności bardzo często nie są sygnalizowane w edycji toruńskiej. Chociażby w kwestii maksymalnej elongacji Merkurego można wskazać na niespójność Historii naturalnej, gdzie w 2, 6, 39, s. 69, podaje Pliniusz, powołując się na Kidenasa i Sosigenesa, wartość $22^{\circ}$, innym razem w 2, 14, 72, s. 85 - $23^{\circ}$ (według lekcji tekstu przyjętej w polskim wydaniu: $20^{\circ}$ ). O. Neugebauer zauważył, że podana wartość $\left(22^{\circ}\right)$ wydaje się co prawda poprawną daną obserwacyjną, występującą w innych zachowanych źródłach, lecz jednocześnie powątpiewa o ścisłości powołania się Pliniusza na Kidenasa, gdyż babilońska teoria planetarna Merkurego operowała innymi kategoriami niż maksymalne elongacje ${ }^{66}$. Śledząc dalej babilońskie koncepcje astronomiczne zawarte w Historii naturalnej, na kolejną natrafić można w 2, 17, 81, s. 91, gdzie mowa o $8^{\circ}$ Barana, Raka, Wagi i Koziorożca jako początku kolejnych pór roku. Obok relacji w 18, 59, 221 passus ten stanowi ważne świadectwo ciągłości stosowania przez Rzymian (m.in. także

59 R.H. Allen, op. cit., s. 185.

60 J. Dobrzycki, J. Włodarczyk, Historia naturalna gwiazdozbiorów, Warszawa 2002, s. 30, 65, 157.

61 O trudnościach tej interpretacji por. J.T. Ramsey, A.L. Licht, The Comet of 44 B.C. and Caesar's Funeral Games, Atlanta 1997, s. 86.

62 Według P. Domenicucciego, Astra Caesarum: astronomia, astrologia e catasterismo da Cesare a Domiziano. Testi e studi di cultura classica, Pisa 1996, s. 66-70, referowane za E. Gee, Ovid, Aratus and Augustus: Astronomy in Ovid's Fasti, Cambridge 2000, s. 159-160.

63 Opracowanie Domenicucciego poddaje krytyce J. Ramsey w recenzji w „Bryn Mawr Classical Review”, bmcr. brynmawr.edu/2000/2000.12.10 [dostęp 30.07.2020].

64 Por. E. Dekker, Illustrating the Phaenomena, Celestial Cartography in Antiquity and the Middle Ages, Oxford 2013, s. 88-90.

65 K. Lippincott, Reflections on the Farnese Atlas: Exploring the Scientific, Literary and Pictorial Antecedents of the Constellations on a Graeco-Roman Globe, [w:] The Imagined Sky - Cultural Perspectives, red. D. Gunzburg, Sheffield - Bristol 2016, s. 55-86.

66 O. Neugebauer, A History of Ancient Mathematical Astronomy, Berlin - Heidelberg - New York 1975, t. 2, s. 612. 
według Maniliusza, Witruwiusza, Kolumelli i innych) jednej z norm systemu B astronomii babilońskiej w ciągu pierwszych pięciu stuleci naszej ery ${ }^{67}$. Warto także odnieść się do wzmianki encyklopedysty $(7,57,193$, s. 121) o obserwacjach ciał niebieskich zapisywanych przez Babilończyków na glinianych tabliczkach sprzed 490-720 tysięcy lat (notabene w przekładzie podano omyłkowo 730). Być może należy wziąć poprawkę (w kwestii tysięcy) na tak wielkie liczby przytaczane przez Pliniusza za Berossosem i Kritodemosem. A może raczej stanowią one tylko symboliczny przedział mający uzmysłowić wartość utrwalania obserwacji prowadzonych przez wiele setek lat i wyraz fascynacji starożytną kulturą ${ }^{68}$ ? Na podstawie podania tej samej wartości przez obu astronomów przypuszczano, że Pliniusz błędnie uznawał Kritodemosa (por. przypis 563: „astronom z IV wieku przed Chr., bliżej nieznany") za ucznia Berossosa. Prawdopodobniej jednak Kritodemos był współczesny Pliniuszowi ${ }^{69}$.

W komentarzu nie wspomniano także o kontrowersji związanej z twierdzeniem Pliniusza o tym, jakoby Kleostratos rozpoznał znaki na pasie zodiaku, przede wszystkim Barana i Strzelca (intellexisse [...] traditur [...] signa deinde in eo Cleostratus et prima Arietis ac Sagittarii)" (2, 6, 31, s. 65), choć odnośnie do niego powstała pokaźna literatura polemiczna ${ }^{70}$. Wiarygodność informacji podanej przez encyklopedystę bywa na ogół kwestionowana, wiadomo bowiem, że grecki zodiak podzielony na 12 znaków ma pochodzenie babilońskie ${ }^{71}$. Fotheringham pomniejszał więc rolę odkrywcy przypisywaną Kleostratosowi, który miałby tylko rozpowszechnić osiągnięcia Babilończyków. Natomiast według jego oponenta, Edmunda J. Webba, zadanie Kleostratosa polegałoby raczej na podziale konstelacji i obserwowaniu prima (signa) Arietis ac Sagittarii, pierwszych gwiazd Barana i Strzelca jako szczególnie interesujących ze względu na ciemne, pozbawione jaśniejszych gwiazd przestrzenie w tych częściach zodiaku. Niejasna wypowiedź Pliniusza była również krytycznie porównywana z przekazanym przez Teona ze Smyrny fragmentem Historii astronomii Eudemosa. Według tego ostatniego dokonanie Kleostratosa należałoby przypisać raczej Ojnopidesowi (to on jako pierwszy miał badać w sposób geometryczny ekliptykę) $)^{72}$.

Komentarz zbywa także milczeniem trudności, jakich przez stulecia przysparzał i wciąż przysparza badaczom niezrozumiały passus 2, 14, 72, s. 85, w którym Pliniusz stara się podać swoje własne, nowatorskie objaśnienie dotyczące ruchów planetarnych, w szczególności Wenus i Merkurego; w toruńskim tłumaczeniu:

67 Ibid., s. 596; O. Pedersen, Some Astronomical Topics in Pliny, s. 179.

68 Hellenistic Astronomy: The Science in Its Contexts, red. A.C. Bowen, F. Rochberg, Leiden - Boston 2020, s. 15; M. Oll, Greek Cultural Translation of Chaldean Learning, Birmingham 2014, rozprawa doktorska, etheses. bham.ac.uk/id/eprint/5679/1/Oll15PhD.pdf [dostęp 15.07.2020], s. 83.

69 Greek Horoscopes, red. O. Neugebauer, H.B. van Hoesen, Philadelphia 1987 (Memoirs of the American Philosophical Society, t. 48), s. 185.

70 Cytowana w: B.L. van der Waerden, History of the Zodiac, "Archiv für Orientforschung” t. 16, 1952-1953, s. 225; idem, Science Awakening II. The Birth of Astronomy, Dordrecht 1974, s. 287.

71 F. Rochberg, Babylonian Astral Science in the Hellenistic World: Reception and Transmission, "CAS LMU e-Series" t. 4, 2010, s. 6-7; K. Stevens, Between Greece and Babylonia: Hellenistic Intellectual History in CrossCultural Perspective, Cambridge 2019, s. 39-40; Geminos's Introduction to the Phaenomena, A Translation and Study of a Hellenistic Survey of Astronomy, wyd. J. Evans, J. Lennart Berggren, Princeton - Oxford 2006, s. 87.

72 Odnośnie do interpretacji dokonań Ojnopidesa: J. Evans, History and Practice of Ancient Astronomy, New York - Oxford 1998, s. 57-58; L. Zhmud, The Origin of the History of Science in Classical Antiquity, Berlin 2006, s. 171. 
Jako że obie planety znajdują się niżej od Słońca i mają apsydy przeciwne do ruchu górnych planet, a ich leżące pod Ziemią części orbit odpowiadają wielkością częściom orbit wspomnianych planet znajdujących się nad Ziemią, dlatego nie mogą znaleźć się dalej, ponieważ krzywizna apsyd nie może osiągnąć większej długości.

Pomimo wstępnej deklaracji, że wydanie polskie opiera się na edycji krytycznej Karla Mayhoffa, w przypadku kontrowersyjnego miejsca (conversas habent utraeque absidas, ut infra Solem sitae, tantumque circulis earum sub terra est, quantum superne praedictarum) dokonano najwyraźniej kontaminacji dwóch wersji, podążając częściowo za Mayhoffem (tantumque circulis earum subter est), dalej zaś za tekstem ustalonym przez Detlefa Detlefsena i przyjętym przez Harrisa Rackhama w jego angielskim przekładzie (tantumque circuli earum sub terra est). Ta druga tradycja rękopiśmienna była niejednokrotnie krytykowana jako pozbawiona sensu i myląca ${ }^{73}$. Czytelnikowi należałoby się więc szczegółowe wyjaśnienie, na czym miałaby polegać przewaga tej lekcji tekstu. Co do używanego przez Pliniusza terminu „apsyda”, definiowanego w 2, 13, 63, s. 81, przypis 82, tłumacze toruńscy powinni również zastrzec, że podawane przez nich w nocie współczesne znaczenie astronomiczne (,jeden z dwóch skrajnych punktów orbity eliptycznej, perycentrum i apocentrum") nie odpowiada pierwotnemu („krąg”, „koło”, „łuk koła”, „krzywizna'), czego dowodził już Aleksander Birkenmajer ${ }^{74}$. Od wieków istniały co prawda kontrowersje w związku z wieloznacznością tego terminu wśród nowożytnych komentatorów. Absides conversae próbowano $\mathrm{w}$ tym passusie interpretować albo jako orbity różniące się położeniem w porównaniu z planetami poza Słońcem (Jacob Ziegler), albo apogea okręgów mimośrodowych, a nie całe orbity (Georg Tannstetter Collimitius). Wszystkie te próby interpretacji epicyklicznej nie nadawały jednak tekstowi zadowalającego sensu. Dlatego dążąc do heliocentrycznego odczytania tekstu, Kopernik i Kepler poszukiwali u Pliniusza spójności za cenę nieodzownych emendacji i nadania jego wypowiedzi takiego kształtu, by przypominała przekaz Marcjana Kapelli. W poszukiwaniu sensu Kepler posuwał się nawet do twierdzenia, że według Pliniusza Merkury i Wenus znajdują się wokół Słońca (circum zamiast infra), a ich leżące poniżej części orbit odpowiadają częściom leżącym powyżej (usuwając z tekstu praedictarum, czyli „wspomnianych planet”) ${ }^{75}$. Należy żałować, że czytelnik wydania polskiego zostaje pozostawiony w nieświadomości powyższych problemów i ich historii, zaledwie zasygnalizowanych w niniejszej recenzji. W komentarzu, poza wzmianką o działaniu promieni słonecznych na ruch planet (które, jak słusznie zauważono, postulował także Witruwiusz), nie wspomniano również o specyficznie Pliniuszowej teorii, czy też hipotezie heliodynamicznej, przypuszczalnie zaczerpniętej od autorów hellenistycznych ${ }^{76}$.

73 Pline I'Ancien, Histoire naturelle. Livre II, tłum. J. Beaujeu, s. 160, przypis 5. B.S. Eastwood, Kepler as Historian of Science: Precursors of Copernican Heliocentrism according to De Revolutionibus I, 10, „Proceedings of the American Philosophical Society" t. 126, 1982, s. 373.

74 Aleksander Birkenmajer uważał, że „w tym miejscu [O obrotach 2, 10, zawierającym kryptocytat z odnośnego passusu Pliniusza - M.J.] przetłumaczenie absidas przez "apsydy» nie byłoby na miejscu”, „pliniuszowa absis jest synonimem kopernikowego orbis”, „frazę sed absidas conversas habent wolno oddać po polsku przez «lecz mają krzywizny inaczej zwrócone», mianowicie inaczej niż sfery Saturna, Jowisza i Marsa", por. M. Kopernik, O obrotach, tłum. M. Brożek, S. Oświecimski, komentarz A. Birkenmajer, J. Dobrzycki, [w:] M. Kopernik, Dzieła wszystkie, t. 2, Kraków - Warszawa 1976, s. 353-354.

75 B.S. Eastwood, op. cit., s. 377-378.

76 Więcej na jej temat w: G. Schiaparelli, Di un' antica ipotesi eliodinamica sul movimento dei pianeti, [w:] Scritti sulla storia della astronomia antica, parte seconda - testi inediti, t. 3, Milano [1998], s. 314-326. Nowe moż- 
Na ile jednak jest ona do pogodzenia z Pliniuszowym strachem przed nieskończonością i wszechświatem heliocentrycznym ${ }^{77}$, pozostaje odrębną kwestią.

Wartość naukowego opracowania mogłyby także znacząco podnieść tabelaryczne ujęcia danych astronomicznych zgromadzonych w Historii naturalnej (wraz z zestawieniem aktualnych, które są niekiedy i niekonsekwentnie przywoływane w przypisach), wykresy i diagramy ruchów planetarnych ${ }^{78}$, schematy (np. róży wiatrów ${ }^{79}$ ) lub - w odniesieniu do dalszych ksiąg geograficznych - mapy czy też inny materiał ilustracyjny, niemal całkowicie nieuwzględniony w edycji (poza ilustracjami na obwolutach).

Przechodząc do krytyki zazwyczaj poprawnego przekładu, na podstawie tomu antropologiczno-zoologicznego zauważyć można, że nowe tłumaczenie zawiera kilka historii o najwyraźniej zmienionym w stosunku do oryginału sensie, przez co osobliwy tekst Pliniusza staje się osobliwy z innych względów. Należy ostrzegawczo odnotować przypadki, kiedy w edycji toruńskiej przekład nie odzwierciedla myśli oryginału. W następującej opowieści $10,96,208$, s. 431 :

Filarchosowi przypisuje się niezwykłe zdarzenie ze żmiją. Podaje on bowiem, że w Egipcie żmija przychodziła regularnie szukać pożywienia na stole jakiejś osoby, żeby karmić swoje młode. Jedno z nich syn gospodarza zabił (quorum ab uno filium interemptum). Żmija, wróciwszy z przyzwyczajenia po jedzenie, spostrzegła, że dokonano zbrodni i zadano śmierć potomkowi (illam reversam ad consuetudinem cibi intellexisse culpam et necem intulisse catulo). Potem już nigdy nie wróciła pod ten dach,

zgodnie z tekstem oryginału ofiarą padł syn gospodarza, a nie młoda żmija, którą następnie zabiła w odwecie jej matka: „potem wydała młode, z których jedno syna jej gospodarza zabiło, ona powróciwszy, według zwyczaju, aby się nakarmić, poznała zbrodnię, zabiła swoje młode" (w tłumaczeniu Józefa Łukaszewicza, t. 4, s. 153) ${ }^{80}$. Wydaje się również, że inaczej należy rozumieć opowieść o rogatych mrówkach indyjskich z 11, 36, 111, s. 487 :

Wydobyte przez nie w zimie złoto Indowie wytapiają (furantur) w letnim upale, kiedy mrówki z powodu żaru chowają się w swych norkach. Jednak podrażnione zapachem uciekają «z nich» i «Indowie» często je ranią, chociaż uciekają na bardzo szybkich wielbłądach (odore sollicitatae provolant crebroque lacerant quamvis praevelocibus camelis fugientes). Tak wielka prędkość i dzikość towarzyszy ich umiłowaniu złota.

liwości odczytania tekstu Pliniusza w kontekście znalezisk papirusów o tematyce astronomicznej przedstawia A. Jones, Pliny on the Planetary Cycles, „Phoenix” t. 45, 1991, s. 148-161.

77 Por. G. Herbert-Brown, Scepticism, Superstition and the Stars: Astronomical Angst in Pliny the Elder, [w:] Vita Vigilia Est: Essays in Honour of Barbara Levick, red. B. Levick, E. Bispham, G. Rowe, E. Matthews, London 2007, s. 113 i 126.

78 Średniowieczną tradycję diagramów inspirowanych tekstem Pliniusza, przedstawiających porządek planet i odległości między nimi, apsydy oraz szerokości, analizuje w wielu swoich pracach Bruce Eastwood, szerzej np. w B.S. Eastwood, G. Graßhoff, Planetary Diagrams for Roman Astronomy in Medieval Europe, ca. 800-1500, „The Transactions of the American Philosophical Society" t. 94, 2004, s. 23-48, gdzie można znaleźć wiele reprodukcji wraz z pełnym wykazem rękopisów.

79 Por. np. rekonstrukcję róży wiatrów w: C. Plinii Secundi Naturalis historiae libri XXXVII, t. 1, wyd. G. Brotier, London 1826, s. 420 oraz Pline I'Ancien, Histoire naturelle. Livre II, tłum. J. Beaujeu, fig. 3 i 4, s. [285].

80 Cytaty w tłumaczeniu Józefa Łukaszewicza pochodzą z: K. Pliniusza Starszego Historyi naturalnej ksiąg XXXVII, t. 3-4, tłum. J. Łukaszewicz, Poznań 1845. 
To raczej mrówki „ranią (rozszarpują) częstokroć Indów, acz na bardzo chyżych wielbłądach uciekających” (Łukaszewicz, t. 4, s. 237). Również w 10, 93, 198, s. 425: „Węże, kiedy nadarza się okazja, szczególnie lubią wino, chociaż potrzebują go do picia niewiele (cum alioqui exiguo indigeant potu)" można doszukać się innego sensu: „choć w ogóle potrzebują bardzo mało napoju". Od oryginału odbiega również swobodne zakończenie passusu o orłach z 10, 4, 13, s. 343: „Wypędzają jedno z dwóch piskląt z braku pokarmu, ponieważ o tej porze roku im samym natura odmówiła pożywienia, przewidując, że potomstwo wszystkich dzikich zwierząt się nie wyżywi (prospiciens ne omnium ferarum fetus raperentur)”, w tłumaczeniu Łukaszewicza, t. 4, s. 13: „W tym bowiem czasie im samym odmawia przyrodzenie pokarmu, zapobiegając, aby płód wszystkich dzikich zwierząt nie był od nich porwanym". Inny sens nadano także zdaniu z 10, 55, 114, s. 389: „To są te ptaki, które widzi się na całym morzu i które nigdy nie oddalają się od lądu tak daleko, jeżeli statki płyną długo, żeby te apodes nie wróciły z powrotem" (Hae sunt, quae toto mari cernuntur, nec umquam tam longo naves tamque continuo cursu recedunt a terra, ut non circumvolitent eas apodes), co znaczyłoby po prostu: „i nigdy nie oddalają się okręty tak daleko od lądu i na tak długi czas, ażeby naokół nich apody nie latały" (Łukaszewicz, t. 4, s. 85). W 11 , 83, 208, s. 531, przetłumaczono omyłkowo: „żadne zwierzę żyworodne oprócz żółwia” (nulli ova gignentium praeter testudinem) - zgodnie z oryginałem powinno być oczywiście jajorodne. Inną ewidentną w przypadku lektury porównawczej pomyłkę znajdzie czytelnik w historii wilkołaka $(8,34,82$, s. 173), gdzie credulitas uległa pomieszaniu z crudelitas, a zamiast stwierdzenia: „Dziwna rzecz, jak daleko posuwa się łatwowierność grecka” padają nieadekwatne w kontekście słowa: „Jak niezwykłe jest to, do czego prowadzi okrucieństwo Greków! Nie ma żadnego bezwstydnego kłamstwa, którego nie można by poświadczyć".

Nieuchwycona i niezrozumiała w przekładzie okazuje się konkluzja następującej historii z $10,72,142$, s. 401 :

Najbardziej jednak pozostanie w pamięci wyśmienite danie aktora tragicznego Ezopa wycenione na sto tysięcy sesterców, w którym podał śpiewające lub naśladujące ludzką mowę ptaki. Każdy z nich został kupiony za sześć tysięcy sesterców. Ten człowiek kierował się tylko tą przyjemnością, żeby jedząc je, zniszczyć odgrywaną rolę człowieka mięsożernego, i nie liczył się zapewne ze swoimi wielkimi dochodami, których przysporzył mu jego głos. Ojciec w pełni godzien syna, który, jak powiedzieliśmy zjadł perły. Nie jest jednak tak, że chciałbym prawdziwie osądzić brzydotę ich obu, ponieważ mniej wstydu przynosi opiewanie (cenasse) największych darów natury niż ludzkich języków.

Sens ostatniego zdania uchwycił poprawnie raczej $w$ dziewiętnastowiecznym przekładzie Łukaszewicz, t. 4, s. 105: „Chyba że przypuścimy, iż mniejszym jest występkiem zjadać największe bogactwo przyrodzenia niż ludzkie języki (tj. ptaków naśladujących głos ludzki)".

Pewne Pliniuszowe wypowiedzi tłumacz stara się wygładzać i nadaje im taki sens, aby tekst nie raził współczesnego czytelnika swoją dosłownością. I tak w 7, 5, 42, s. 51:

I dlatego chodzenie oraz, prawdę mówiąc, wszystko może mieć znaczenie dla ciężarnej, jako że przyszłe matki, które jedzą bardziej słone pokarmy, rodzą dzieci pozbawione paznokci, a jeśli wykonują jakąś pracę fizyczną, z trudem oddychają (si 
respiravere, difficilius enitantur). Ziewanie podczas ciąży jest śmiertelne, podobnie jak stosunek powoduje poronienie (sicut sternuisse a coitu abortivum),

podczas gdy u Łukaszewicza, t. 3, s. 35, przeczytamy tu dosłownie „a oddychając, rodzą ciężej [...] jako też kichanie po spółkowaniu sprawia poronienie". Zastanawiające wydaje się w tłumaczeniu zakończenie wypowiedzi z 7, 16, 75, s. 65: „Jest rzeczą pewną, że dzieci rodzą się, mając półtorej stopy wysokości, a niektórzy więcej, i że kiedy mają trzy lata, oblicza się czas ich życia" (in trimatu inplentes vitae cursum), podczas gdy Pliniusz stwierdza po prostu: „i w trzecim roku kończą bieg życia”. Tautologiczny i wygładzony przekład pojawia się w 11, 94, 230, s. 541: „Tylko człowiekowi w młodości rosną włosy. Jeżeli to się nie zdarza, zarówno mężczyzna, jak i kobieta, pozostają łysi" (Pubescit homo solus, quod nisi contigit, sterilis in gignendo est, seu mas seu femina), co w archaicznym, lecz lepiej oddającym sens tłumaczeniu Łukaszewicza, t. 4, s. 323, brzmi: „Tylko samemu człowiekowi rzucają się włosy około części rodnych, gdy to nie nastąpi, niezdatnym jest do płodzenia, bądź to mężczyzna, bądź też kobieta".

Osobną grupę translatorskich lapsusów stanowią tłumaczenia przeciwstawne. W 7, 3, 37, s. 49: „kiedy urodzą się bliźnięta, rzadko zdarza się, żeby położnica albo jeden z bliźniaków nie przeżył (editis geminis raram esse aut puerperae aut puerperio praeterquam alteri vitam). Jeszcze rzadziej zdarza się zaś, że kiedy rodzą się bliźnięta różnej płci, przeżywają oboje”, właściwie: „Przy rodzeniu się bliźniąt rzadką jest rzeczą, aby matka albo jedno z dzieci przy życiu zostało. Jeżeli zaś bliźnięta obydwóch są płci, rzadziej jeszcze ocaleją" (Łukaszewicz, t. 3, s. 31). Wśród przypadków utraty pamięci według 7, 24, 90, s. 71, czytamy: „Ktoś, kto spadł z wysokiego dachu, rozpoznał (cepit oblivionem) matkę, krewnych i przyjaciół”, oczywiście „przestał rozpoznawać”. Z kolei w 8, 83, 225, s. 239: „Dziwne jest to, że natura nie tylko przeznaczyła różne zwierzęta do życia w różnych krainach, lecz także to, że pozwoliła (negasse) niektórym gatunkom przebywać w tym samym miejscu na tym samym terenie” powinno być „nie pozwoliła”. Do zamieszania dochodzi także w tłumaczeniu 11, 28, 84, s. 475: „Te same owady snują pajęczynę, kiedy jest ładna pogoda, a przestają, gdy się chmurzy (iidem sereno non texunt, nubilo texunt), i dlatego obfita pajęczyna zapowiada deszcze”, przeciwnie: „Nie tkają w dzień pogodny, tkają zaś w dzień pochmurny". Natomiast w 11, 49, 134, s. 497: „Uczeni twierdzą, że (mózg) nie jest niczym innym jak tylko szpikiem, ponieważ gotowany twardnieje (Aliud esse quam medullam eruditi docent, quoniam coquendo durescat)" nagromadzenie polskich przeczeń skutkuje twierdzeniem, podczas gdy oryginalny sens jest tu istotnie przeczący: „Nie jest to ta sama substancja, która stanowi szpik kostny, bo przy gotowaniu twardnieje" (w tłumaczeniu Ireny i Tadeusza Zawadzkich) ${ }^{81}$. Do zaprzeczenia pierwotnej myśli Pliniusza dochodzi również w 11, 50, 136, s. 499: „Tylko człowiek ma ruchome uszy” (Aures homini tantum immobiles), zgodnie z oryginałem mają być bowiem „nieruchome”. Nowe tłumaczenie tak wielkiego i zróżnicowanego treściwo dzieła nie jest niestety wolne od różnych nieporozumień, często niewielkich i łatwych do wyeliminowania, czasem zaś większych błędów. 
Toruńska edycja bilingwiczna Historii naturalnej Pliniusza Starszego z pewnością zasługuje na uznanie ze względu na ogrom podjętej pracy, którego egzemplifikacją jest zestawienie setek danych geograficznych, locorum nuda nomina i zidentyfikowanie wielu nazw dawnych miejscowości z ich współczesnymi odpowiednikami. Jeśli jednak oceniać sposób naukowego opracowania, szczególnie kosmologicznej księgi drugiej, pozostawia ona badaczy z poczuciem niedosytu, lukami w komentarzu i niewykorzystanymi możliwościami bibliograficznymi. Rewizji i krytycznej lektury porównawczej domaga się także przekład drugiego tomu antropologiczno-zoologicznego, niekiedy istotnie nieodzwierciedlający sensu oryginalnej wypowiedzi Pliniusza.

\section{Bibliografia}

\section{Wydania i przekłady Pliniusza Starszego}

Pliniusz, Historia naturalna, T. I: Kosmologia i geografia, księgi II-VI, tekst, wstęp, tłum. i komentarz I. Mikołajczyk, N. Rataj, E. Twarowska-Antczak, K. Antczak, red. I. Mikołajczyk, T. II: Antropologia i zoologia, księgi VII-XI, tekst, wstęp, tłum. i komentarz I. Mikołajczyk, Toruń 2017-2019.

Pliniusz, Historia naturalna (wybór), tłum. i wstęp I. i T. Zawadzcy, rozdz. 6 wstępu „Pliniusz w Europie" L. Hajdukiewicz, Wrocław - Kraków 1961.

Pliniusz, Historyi naturalnej ksiąg XXXVII, t. 1-4, tłum. J. Łukaszewicz, Poznań 1845.

Pliniusz, Histoire naturelle. Livre II, tekst, tłum. i komentarz J. Beaujeu, Paris 1950.

Pliniusz, Natural History, t. 1-4, tłum. H. Rackham, London 1960-1967.

Pliniusz, The Natural History, t. 1, tłum. J. Bostock, H. T. Riley, London 1855.

Pliniusz, Naturalis historiae libri XXXVII, t. 1 (ks. 1-6), wyd. C. Mayhoff, Leipzig 1906.

Pliniusz, Naturalis historiae libri XXXVII, t. 1, wyd. G. Brotier, London 1826.

\section{Inne źródła}

Arystoteles, Dzieła wszystkie. T. 2, Fizyka, O niebie, o powstawaniu i niszczeniu, Meteorologika, O świecie, Metafizyka, tłum., wstępy, komentarze K. Leśniak, A. Paciorek, L. Regner, P. Siwek, Warszawa 1990.

Cyceron, Pisma filozoficzne. T. 1, O naturze bogów, O wróżbiarstwie, O przeznaczeniu, tłum. W. Kornatowski, komentarz K. Leśniak, Warszawa 1960.

Diogenes Laertios, Żywoty i poglądy słynnych filozofów, tłum. I. Krońska, wstęp K. Leśniak, Warszawa 2004.

Geminos's Introduction to the Phaenomena, A Translation and Study of a Hellenistic Survey of Astronomy, wyd. J. Evans, J. Lennart Berggren, Princeton - Oxford 2006.

Kopernik M., O obrotach, tłum. M. Brożek, S. Oświecimski, komentarz A. Birkenmajer, J. Dobrzycki, [w:] M. Kopernik, Dzieła wszystkie, t. 2, Kraków - Warszawa 1976.

Ioannes Lydos, Liber de ostentis et calendaria Graeca omnia, wyd. C. Wachsmuth, Leipzig 1897.

Manilius, Astronomica, tłum. G.P. Goold, London 1997 (Loeb Classical Library, t. 469).

Seneka, Pisma filozoficzne. T. 3, O zjawiskach natury, tłum. L. Joachimowicz, Warszawa 1969. 
Witruwiusz, O architekturze ksiąg dziesięć, tłum. K. Kumaniecki, wstęp A. Sadurska, Warszawa 1999.

Ziegler J., In C. Plinii De naturali historia librum secundum commentarius, Basel 1531.

\section{Literatura przedmiotu}

Allen R.H., Star-Names and Their Meanings, New York 1936.

Beagon M., Roman nature: the thought of Pliny the Elder, Oxford - New York 1992.

Bowen A.C., The Art of the Commander and the Roman Emergence of Predictive Astronomy, [w:] Science and Mathematics in Ancient Greek Culture, red. C.J. Tuplin, T.E. Rhill, New York 2002, DOI 10.1093/acprof:oso/9780198152484.003.0005.

Broek R. van der, The Myth of the Phoenix according to Classical and Early Christian Traditions, Leiden 1972.

Clark D.H., Stephenson F.R., The Historical Supernovae, Oxford New - York Toronto - Sydney - Paris - Frankfurt 1977, DOI 10.1016/C2013-0-10100-6.

Dekker E., Illustrating the Phaenomena, Celestial Cartography in Antiquity and the Middle Ages, Oxford 2013, DOI 10.1093/acprof:oso/9780199609697.001.0001.

Dobrzycki J., Historia naturalna gwiazdozbiorów I: wstęp do studiów nad ikonografią nieba gwiaździstego, „Kwartalnik Historii Nauki i Techniki” t. 34, 1989, nr 4, s. 891-900. Dobrzycki J., Włodarczyk J., Historia naturalna gwiazdozbiorów, Warszawa 2002.

Doody A., Pliny's Natural History: Enkuklios Paideia and the Ancient Encyclopedia, „Journal of the History of Ideas" t. 70, 2009, s. 1-21, DOI 10.1353/jhi.0.0021.

Dreyer J.L.E., On the Origin of Ptolemy's Catalogue of Stars, "Monthly Notices of the Royal Astronomical Society" t. 77, 1917, s. 528-539, DOI 10.1093/mnras/77.7.528.

Eastwood B.S., Kepler as Historian of Science: Precursors of Copernican Heliocentrism according to De Revolutionibus I, 10, "Proceedings of the American Philosophical Society" t. 126, 1982, s. 367-394.

Eastwood B.S., Graßhoff G., Planetary Diagrams for Roman Astronomy in Medieval Europe, ca. 800-1500, "The Transactions of the American Philosophical Society" t. 94, 2004, DOI 10.2307/20020363.

Evans J., History and Practice of Ancient Astronomy, New York - Oxford 1998.

Fotheringham J.K., The New Star of Hipparchus, and the Dates of the Birth and Accession of Mithridates, "Monthly Notices of the Royal Astronomical Society" t. 79, 1919, s. 162-167, DOI 10.1093/mnras/79.3.162.

Gee E., Ovid, Aratus and Augustus: Astronomy in Ovid's Fasti, Cambridge 2000.

Goldstein B.R., Bowen A.C., Pliny and Hipparchus's 600-Year Cycle, „Journal for the History of Astronomy" t. 26, 1995, s. 155-158, DOI 10.1177/002182869502600204.

Greek Horoscopes, red. O. Neugebauer, H.B. van Hoesen, Philadelphia 1987 (Memoirs of the American Philosophical Society, t. 48).

Hahm D.E., Origins of Stoic Cosmology, Ohio 1977.

Halley E., Emendationes et notae in tria loca vitiose edita in textu vulgato Naturalis Historiae C. Plinii, „Philosophical Transactions” t. 16, 1686-1692, s. 535-540, DOI 10.1098/ rstl.1686.0101.

Healy J.F., Pliny the Elder on Science and Technology, Oxford 2005.

Hellenistic Astronomy: The Science in Its Contexts, red. A.C. Bowen, F. Rochberg, Leiden Boston 2020, DOI 10.1163/9789004400566. 
Herbert-Brown G., Scepticism, Superstition and the Stars: Astronomical Angst in Pliny the Elder, [w:] Vita Vigilia Est: Essays in Honour of Barbara Levick, red. B. Levick, E. Bispham, G. Rowe, E. Matthews, London 2007, s. 113-126, DOI 10.1111/j.20415370.2007.tb02467.x.

Jones A., Pliny on the Planetary Cycles, „Phoenix" t. 45, 1991, s. 148-161, DOI $10.2307 / 1088552$.

Lippincott K., Reflections on the Farnese Atlas: Exploring the Scientific, Literary and Pictorial Antecedents of the Constellations on a Graeco-Roman Globe, [w:] The Imagined Sky - Cultural Perspectives, red. D. Gunzburg, Sheffield - Bristol 2016.

Lloyd G.E.R., Nauka grecka po Arystotelesie, tłum. J. Lesiński, Warszawa 1998.

Neugebauer O., A History of Ancient Mathematical Astronomy, t. 1-3, Berlin - Heidelberg - New York 1975.

Oll M., Greek Cultural Translation of Chaldean Learning, Birmingham 2014, etheses. bham. ac.uk/id/eprint/5679/1/Oll15PhD.pdf [dostęp 15.07.2020].

Pedersen O., Early Physics and Astronomy: A Historical Introduction, Cambridge 1993.

Pedersen O., Some Astronomical Topics in Pliny, [w:] Science in the Early Roman Empire: Pliny the Elder, his Sources and Influence, red. R. French, F. Greenaway, London - Sydney 1986, s. 162-196.

Pedersen O., A Survey of the Almagest with Annotation and New Commentary by Alexander Jones, New York - Dordrecht - Heidelberg - London 2011, DOI 10.1007/9780-387-84826-6.

Ramsey J.T., Licht A.L., The Comet of 44 B.C. and Caesar's Funeral Games, Atlanta 1997.

Ramsey J.T., Patrizio Domenicucci, Astra Caesarum: astronomia, astrologia e catasterismo da Cesare a Domiziano. Testi e studi di cultura classica; 16. Pisa: ETS, 1996. 191 pages (review), bmcr.brynmawr.edu/2000/2000.12.10 [dostęp 30.07.2020].

Rochberg F., Babylonian Astral Science in the Hellenistic World: Reception and Transmission, „CAS LMU e-Series” t. 4, 2010, s. 1-11.

Schiaparelli G., Di un' antica ipotesi eliodinamica sul movimento dei pianeti, [w:] Scritti sulla storia della astronomia antica, parte seconda - testi inediti, t. 3, Milano [1998], s. 314-326.

Stevens K., Between Greece and Babylonia: Hellenistic Intellectual History in Cross-Cultural Perspective, Cambridge 2019, DOI 10.1017/9781108303552.

Waerden B.L. van der, History of the Zodiac, "Archiv für Orientforschung” t. 16, 19521953, s. 216-230.

Waerden B.L. van der, Science Awakening II. The Birth of Astronomy, Dordrecht 1974, DOI 10.1007/978-94-017-2952-9.

Włodarczyk J., Early Star Catalogues or What Do We Really Know About Ancient Observational Procedures of Positional Measurements, [w:] Science in Contact at the Beginning of Scientific Revolution, red. J. Zamrzlová, Prague 2004 (Acta historiae rerum naturalium necnon technicarum, New Series, t. 9), s. 81-103.

Włodarczyk J., Księżyc w nauce i kulturze Zachodu, Poznań 2012.

Zhmud L., The Origin of the History of Science in Classical Antiquity, Berlin 2006. 
dr Maria Jóźwicka jest adiunktem w Instytucie Historii Nauki im. L. i A. Birkenmajerów PAN.

e-mail: m.r.jakubowska@gmail.com

Data zgłoszenia artykułu: 11 sierpnia 2020

Data przyjęcia do druku: 21 sierpnia 2020 